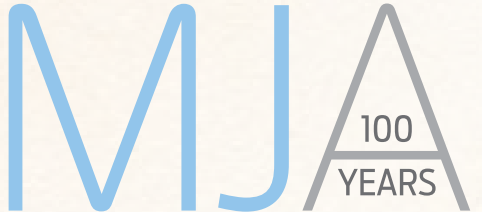

The Medical Journal of Australia - 1914-2014 www.mja.com.au

Editor-in-Chief

Stephen Leeder, AO, MD, FRACP

Deputy Editors

Tatiana Janusic, MB BS, DPH, FRACGP

Wendy Morgan, MB ChB, MPH(Hons), FRACGP

Astika Kappagoda, MB BS, MPhil, PhD

Robyn Godding, MBBS, MPH, FRACMA

Christine Gee, BSc(Med), MBBS(Hons)

Diana McKay, FRANZCP, MHM, AFRACMA

Deputy Editor, Poetry and Fiction

Leah Kaminsky, MB BS, BA

Senior Assistant Editors

Elsina Meyer, BSc

Katherine McLeod, BSc(Hons)

Assistant Editors

Christine Binskin, BSC

Suzanne Habjan, BSc(Hons), PhD

Olivia Wroth, BVSC

Graeme Prince, BAppSc, BA(Hons), MA(Hons)

Sonya Chervonsky, BA

Scientific Proofreaders

Gita Sankaran, BSc, MIM, PhD

Kathryn Tuckwell, MBBS, BA(Hons)

Librarian Jackie Holman, BAComm(Info)

MJA Journalist/Careers Editor Cate Swannell, BA

Editorial Administrator Kerrie Harding

Editorial Assistant Zane Colling

Production Glenn Carter, Peter Humphries

\section{Electronic Publishing}

Peter Hollo, BSc(Hons), BA, LMusA

Ross Sandoval, BComp

Publishing Assistant Wade Clarke, BAComm

\section{CONTACT THE MJA}

AMPCo House, 277Clarence Street, Sydney,

NSW 2000 ABN 20000005854.

Post: The MJA, Locked Bag 3030, Strawberry Hills,

NSW 2012. Tel: (02) 9562 6666. Fax: (02) 95626699.

mja@mja.com.au

INSTRUCTIONS TO AUTHORS: https://www.mja.

com.au/journal/mja-instructions-authors

ADVERTISING AND COMMERCIAL REPRINTS

Sales and Marketing Manager David Kelly

Commercial Manager Delores D'Costa

Bus Dev \& Senior Account Manager Mike Mata

Account Manager Sarah Lander

Advertising Coordinator Susantika Susantika

Tel: (02) 95626621.

advertising@mja.com.au, reprints@mja.com.au

\section{SUBSCRIPTIONS Jane Anderson}

Tel: (02) 9562 6617. subscriptions@mja.com.au

2014 Annual subscription (+ GST):

Individual: RRP A $\$ 410.00$ (new), A\$350.00 (renewal).

Institutions: on application.

The Medical Journal of Australia (MJA) is published on the lst and 3rd Monday of each month by the Australasian Medical

Publishing Company Proprietary Limited (AMPCo), a wholly

owned subsidiary of the Australian Medical Association (AMA).

The statements or opinions that are expressed in the MJA

reflect the views of the authors and do not represent the

opinions or policies of the MJA or the AMA unless so stated.

None of AMPCo, the AMA or any of its servants and agents will

have any liability in any way arising from information or advice

that is contained in the MJA. Although all accepted advertising

material is expected to conform to ethical and legal

standards, such acceptance does not imply endorsement by

the MJA. The MJA is intended for medical professionals and is

provided without warranty, express or implied.

All literary matter in the MJA is covered by copyright, and must not be reproduced, stored in a retrieval system, or transmitted in any form by electronic or mechanical means, photocopying, or recording, without written permission.

(c) AMPCo, 2014 · Printed by Webstar Australia.

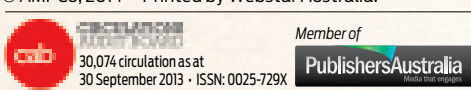

\title{
Highlights from our archives
}

Muscle contraction
is a normal reaction
to stress

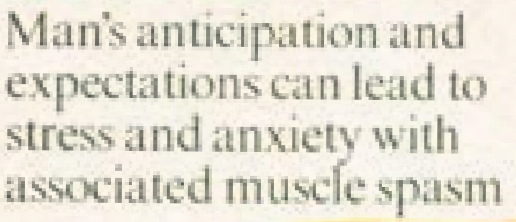

associated muscie spasm

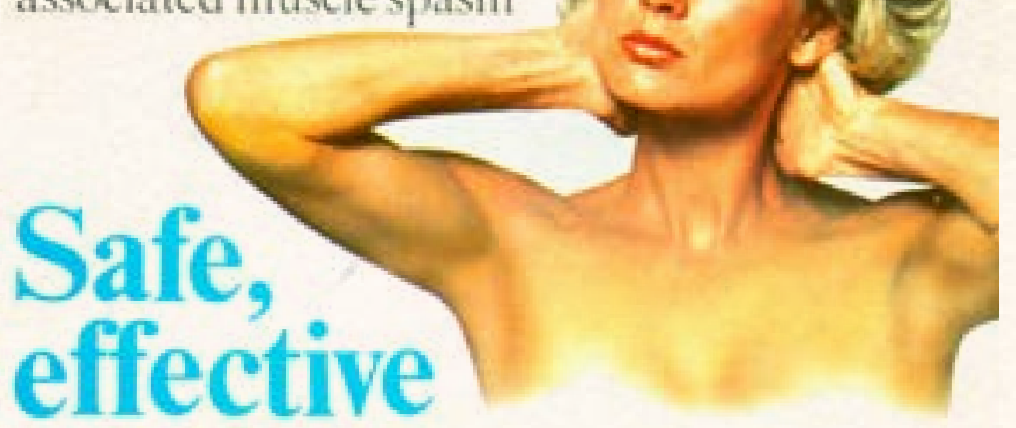

This advertisement for a well known tranquiliser ran in the 26 August 1978 issue of the MJA. Were they trying to get women to relax before their men's "anticipation and expectation" became too much, or is this naked woman just a representative of "mankind"? The answer is lost in the mists of time.

\section{On the effects of war on medical research}

[These] were not 10 ordinary years.

In some respects the war provided stimulation and material that might have been impossible under other circumstances.

It also placed in the hands of the authorities an almost unlimited supply of men to do the work.

In this way the fascination of research work reached a greater number than would have been the case had there been no war.

On the other hand the abnormal years involved certain grave disadvantages to the steady progress of medical research.

In the first place the financial stringency restricted the support that the public could provide out of consolidated revenue.

For a time it probably reduced the size of those munificent gifts that wise rich men make to scientific research.

And it stemmed the movement for a time in the direction of creating lucrative careers for men and women with genius for research.

Then it diverted the work of many from hygiene and preventive medicine of peace time to that connected with special problems in preventive and curative medicine rendered necessary by the disaster of war.

It is true that many of the war problems in hygiene can be applied to ordinary life conditions and in consequence the war may have hastened progress under the impetus of necessity.

But other problems have fortunately little application to civil life and the need to push aside other work in order that these war inquiries might be prosecuted, has not been advantageous.

Lastly a great deal of work has been carried out rapidly in the full light of the public gaze. It is not impossible that some of the investigators have sought a short cut to eminence.

The result of hurried work and forced results is that it is unreliable and soon has to be disregarded.

There are no short cuts in science. Every step must be taken deliberately and in proper order.

Editorial, 7 March 1924 (edited extract)

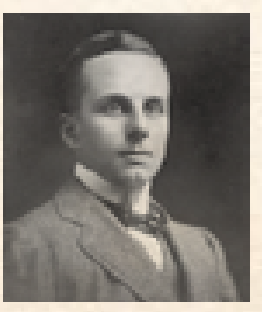

\section{Lost genius}

Gordon Clunes Mackay Mathison was revered as "one fitted by personality, knowledge, judgement, energy and originality to become a true leader in medical science". A University of Melbourne graduate (1905), he was named as the first director of the Walter and Eliza Hall Institute of Medical Research. He died on 18 May 1915, from wounds received in the Battle of Gallipoli, before he could take up the position. 


\section{Sanofi-Aventis \\ Vivaxim \\ p60 (to come)}

